\title{
Eksplorasi Limbah Lokal Indramayu Sebagai Bahan Baku Alat Peraga Media Analog Dan Efektivitasnya Terhadap Hasil Belajar Biologi
}

\author{
Nur Subkhi $^{1)}$, Anilia Ratnasari ${ }^{2)}$, Idah Hamidah ${ }^{3)}$ \\ ${ }^{123}$ Departemen Pendidikan Biologi, Fakultas Keguruan dan Ilmu Pendidikan, Universitas Wiralodra \\ Email: nursubkhi@unwir.ac.id \\ Email: anilia@unwir.ac.id \\ Email: idah.hamidah@unwir.ac.id
}
APA Citation: Subkhi, N., Ratnasari, A., \& Hamidah, I. (2020). Eksplorasi Limbah Lokal Indramayu Sebagai Bahan Baku Alat Peraga Media Analog Dan Efektivitasnya Terhadap Hasil Belajar Biologi. Quagga: Jurnal Pendidikan dan Biologi, 12(1), 31- 43. doi: 10.25134/quagga.v12i1.2138.

Received: 15-11-2019

Accepted: 11-01-2020

Published: 20-01-2020

\begin{abstract}
Abstrak: Fakta di lapangan guru memiliki keterbatasan dalam pengembangan alat peraga sebagai media ajar untuk materi yang abstrak, sehingga hasil belajar biologi siswa belum dapat mencapai KKM. Jenis penelitian ini merupakan penelitian pengembangan $(R \& D)$ yang diadaptasi sesuai kebutuhan peneliti dengan tahapan mengidentifikasi potensi limbah, mendesain produk, memvalidasi produk ke ahli, uji coba skala kecil, revisi produk, uji skala besar untuk data keefektifan media, analisis data menggunakan uji $t$ untuk hasil posttest dan persentase (\%) untuk data hasil obsevasi serta angket. Adapun subjek penelitian untuk uji coba skala luas yaitu 3 sekolah dimana masing-masing sekolah memiliki peringkat berbeda (sumber sumber Kantor Cabang Dinas Pendidikan Wilayah IX Provinsi Jawa Barat). Instrumen yang digunakan yaitu tes esai, lembar observasi keaktifan siswa, dan lembar angket moivasi siswa. Hasil penelitian ini menunjukkan hasil validasi ahli dengan kategori layak digunakan dan sedikit revisi, hasil uji skala kecil interpretasi respon siswa dengan kategori baik, hasil efektivitasnya posttes memperoleh rata-rata sebesar 15,96, hasi keaktian siswamemperoleh rata-rata sebesar 74,65 dengan kategori baik, hasil rata-rata motivasi belajar siswa 69,12 dengan kategori tinggi. Berdasarkan hasil penelitian dapat disimpulkan bahwa Eksplorasi Limbah Lokal Indramayu Sebagai Bahan Baku Alat Peraga Media Analog efekif terhadap hasil belajar Biologi pada pembelajaran sistem peredaran darah.
\end{abstract}

Keywords:Limbah Lokal Indramayu; Alat Peraga Media Analog; Pembelajaran Sekolah.

\begin{abstract}
Facts in the field of teachers have limitations in the development of teaching aids as teaching media for abstract material, so that student learning outcomes have not been able to reach the KKM. This type of research is a research and development $(R \& D)$ adapted to the needs of researchers by exploring potential resources, designing products, validating products to experts (validators), small-scale trials, product revisions, large-scale tests for data effectiveness media, data analysis using $t$-tests for posttest results and percentages (\%) for observational data and questionnaires. As research subjects for large-scale trials (broad) namely 3 schools where each school has a different ranking based on the results of the SMA SMA / MA 2019 (source source Branch Office Education Office Region IX West Java Province). The instruments used were essay tests, student activity observation sheets, and student motivation questionnaire sheets. The results of this study indicate the results of expert validation by the category appropriate to use and a little revision, the results of small-scale tests obtained by the interpretation of students with good categories. Results of USB data processing and analysis obtained an average of 15.96 results posttest effectiveness, the results of student activity gained an average value of 74.65 in both categories, the average result of students' learning motivation is 69.12 with the high category. Based on the results of the study it can be concluded that the exploration of Indramayu Local Waste as a Raw Material Analog Viewer Media is effective on learning outcomes of Biology in the learning of the circulatory system.
\end{abstract}

Keywords: Indramayu Local Waste; Analog Media Props; School Learning. 
Quagga: Jurnal Pendidikan dan Biologi

Volume 12, Nomor 1, Januari 2020, pp.31-43
p-ISSN 1907-3089, e-ISSN2651-5869

https://doi.org/10.25134/quagga.v12i1.2138

\section{PENDAHULUAN}

Perubahan tingkah laku siswa sebagai hasil belajar yaitu mencakup hasil belajar kognitif siswa, keaktifan siswa dan motivasi siswa. Hasil belajar siswa yang baik dihasilkan dari pengalaman belajar yang baik pula, sehingga tujuan pembelajaran dapat tercapai.

Berdasarkan laporan kegiatan PPL Mahasiswa pendidikan Biologi Universitas Wiralodra, bahwa di sekolah menengah atas kabupaten Indramayu dalam pembelajaran Biologi masih menggunakan pembelajaran konvensional, sehingga dari hasil observasi di beberapa sekolah diperolah sekitar $65 \%$ pemahaman materi siswa belum mencapai KKM, keaktifan siswa di kelas masih kurang dan siswa juga kurang termotivasi khususnya pada materi ajar yang dianggap sulit. Selain itu, dari hasil penelusuran alumni sebagai guru, berpendapat bahwa di sekolah guru mengalami keterbatasan dalam penggunaan dan pengembangan alat peraga sebagai media pembelajaran salah satu contohnya pada materi sistem peredaran darah.

Proses pembelajaran Biologi meliputi materi yang bersifat abstrak dan kompleks, oleh karena itu dibutuhkan alat bantu untuk memvisualisasikan materi ajar dengan melalui alat peraga sebagai salah satu media pembelajaran (Nurmaningsih, dkk., 2013). Alat peraga dapat digunakan untuk memperagakan dan menggambarkan mekanisasi konsep materi. Alat peraga juga dapat menyalurkan pesan sehingga lebih sistematis dalam proses pembelajaran dandapat dengan mudah dipahami oleh siswa (Faisal, 2010). Pembuatan alat peraga membutuhkan bahan baku dasar yang digunakan salah satunya yaitu dari limbah atau barang bekas.

Limbah merupakan sesuatu yang dianggap sudah tidak layak pakai atau sering dianggap sampah, sebagai contoh limbah lokal Indramayu sebagai daerah pesisir banyak menghasilkan limbah dari berbagai jenis hewan pesisir pantai yang dapat dimanfaatkan sebagai bahan baku alat peraga media analog. Dalam hal ini, limbah cangkang kerang. Sesuai dengan hasil penelitian sebelumnya yaitu alasan eksplorasi limbah karena memiliki kelebihan diantaranya unik, mudah didapat, murah, mengurangi sampah, dan cara kerjanya tidak sulit (Fransina T.N., dan Theodora S. N. M., 2018).

Alat peraga media analog dapat dijadikan sarana interaksi antar siswa dalam proses pembelajaran, karena siswa dapat saling berkomunikasi menjelaskan kembali materi dengan menggunakan alat peraga media analog sesuai kurikulum 2013, yang menekankan pembelajaran berpusat pada siswa (student centered), diharapkan dapat memicu keaktifan dan motivasi sejalan dengan pendapat Arsyad (2017) media analog dapat membangkitkan motivasi kegiatan belajar siswa. Penggunaan alat peraga dan media pembelajaran sebaiknya disesuaikan dengan penerapan strategi, metode, serta model pembelajaran sebagai faktor pendukung keberhasilan pembelajaran Biologi.

Oleh karena itu, berdasarkan permasalahan tersebut tujuan penelitian ini yaitu eksplorasi limbah lokal indramayu sebagai bahan baku alat peraga media analog dan efektifitasnya terhadap hasil belajar kognitif siswa, memunculkan keaktifan dan motivasi siswa.

\section{METODOLOGI PENELITIAN}

Jenis penelitian ini merupakan penelitian pengembangan $\mathrm{R} \& \mathrm{D}$, rancangan yang digunakan mengacu pada Sugiyono (2015) dan Brog \& Gall (1983) yang diadaptasi sesuai dengan kebutuhan peneliti (dalam Hanafi, 2017). Pengembangan alat peraga media analog berbahan baku limbah lokal Indramayu di mulai dengan prosedur langkah-langkah sebagai berikut, yaitu 1) Mengidentifikasi masalah dan potensi limbah lokal Indramayu, 2) kemudian mendesain produk alat peraga media analog, 3) dilanjutkan melakukan validasi produk oleh ahli (validator), 4) kemudian merevisi produk, 5) setelah itu dilakukan uji coba produk alat peraga media analog dengan uji lapangan skala kecil yang melibatkan 17 orang siswa dengan menggunakan instrumen angket untuk melihat respon siswa terhadap alat peraga media analog, 6) kemudian merevisi dan menyempurnakan produk alat peraga media analog untuk uji lapangan skala besar dalam pembelajaran biologi materi sistem peredaran darah, 7) pegumpulan data efektivitas terhadap 
hasil belajar kognitif dengan menggunakan instrumen soal tes esai, 8) mengukur keaktifan, dan motivasi siswa dengan menggunakan instrumen berupa lembar observasi dan angket untuk motivasi.

Subjek uji lapangan skala besar yaitu sampel melibatkan 82 siswa dari 3 SMA yang levelnya berbeda berdasarkan nilai UN tahun 2019. Diperoleh kelas XI MIPA SMA Negeri 1 Sindang, XI MIPA SMA Negeri 1 Lohbener, dan XI MIPA SMA Negeri 1 Lelea (KCD Pendidikan Provinsi Jawa Barat), setelah itu dilakukan analisis data dengan menggunakan uji $\mathrm{t}$ post test one group design, dan hasil observasi serta angket dalam bentuk persentase.

\section{HASIL DAN PEMBAHASAN}

Jenis data yang diperoleh yaitu deskripsi data penelitian dimulai dari 1). Hasil validasi produk oleh ahli, 2). Hasil uji coba skala kecil, 3) Data skor hasil belajar siswa USB yang diperoleh dari teknik pemberian tes kognitif (posttest) materi sistem peredaran darah, 2) Data persentase skor keaktifan belajar siswa USB yang diperoleh dari teknik pengisian lembar observasi oleh observer, dan 3) Data persentase skor motivasi belajar siswa USB yang diperoleh dari teknik pengisian angket.

\section{Data Hasil Validasi Produk}

Alat peraga media analog berbahan baku limbah lokal indramayu di validasi oleh ahli yang hasilnya disajikan pada tabel 1 , sebagai berikut:

Tabel 1. Hasil Validasi Produk

\begin{tabular}{lcl}
\hline \multicolumn{1}{c}{ Aspek } & Persentase & \multicolumn{1}{c}{ Keterangan } \\
\hline Kesesuaian & $100 \%$ & $\begin{array}{l}\text { Sangat baik, sesuai dengan } \\
\text { materi biologi dan tujuan } \\
\text { pembelajaran. }\end{array}$ \\
Kemudahan & $65.63 \%$ & $\begin{array}{l}\text { Cukup baik, perlu } \\
\text { disederhanakan agar } \\
\text { mudah dalam penggunaan, } \\
\text { dan penyimpanan. } \\
\text { Sangat baik, karena } \\
\text { bersifat baru dan kreatif. } \\
\text { Kemenarikan }\end{array}$ \\
Kebermanfaatan & $91.67 \%$ & $\begin{array}{l}\text { Saik, karena } \\
\text { memudahkan siswa dalam } \\
\text { memahami materi. }\end{array}$ \\
\hline
\end{tabular}

Dari hasil persentase penilaian validator $(2$ ahli) terhadap produk untuk alat peraga media analog yang berbahan baku limbah lokal Indramayu dari aspek yang dinilai atau validasi aspek "kesesuaian" memperoleh dengan kategori sangat baik. Sedangkan aspek "kemudahan" dalam kategori cukup baik, sehingga perlu dilakukan perbaikan media/ sedikit revisi. Untuk aspek "kemenarikan" termasuk kategori sangat baik. Dan aspek "kebermanfaatan" kategori sangat baik. Berdasarkan hasil tersebut, alat peraga media analog layak digunakan lebih lanjut dalam pembelajaran biologi.

\section{Data Hasil Uji Coba Skala Kecil (USK)}

Hasil uji coba skala kecil (USK) dengan instrumen interpretasi angket respon terhadap alat peraga media analog hasilnya disajikan pada tabel 2, Sebagai berikut:

Tabel 2. Hasil Respon Siswa Uji Coba Skala Kecil

\begin{tabular}{|c|c|c|c|}
\hline Pernyataan & Ya & Tidak & Keterangan \\
\hline 1 & $94 \%$ & $6 \%$ & $\begin{array}{l}\text { Siswa menyukai demontrasi } \\
\text { penggunaan Alat peraga } \\
\text { media analog }\end{array}$ \\
\hline 2 & $72 \%$ & $38 \%$ & $\begin{array}{l}\text { Alat peraga media analog } \\
\text { dapat sarana interaksi } \\
\text { komunikasi siswa }\end{array}$ \\
\hline 3 & $78 \%$ & $22 \%$ & $\begin{array}{l}\text { Alat peraga media analog } \\
\text { dapat memfokuskan siswa, } \\
\text { karena konsep materi } \\
\text { peredaran darah lebih jelas }\end{array}$ \\
\hline 4 & $74 \%$ & $36 \%$ & $\begin{array}{l}\text { Alat peraga media analog } \\
\text { dapat memotivasi siswa } \\
\text { dalam pembelajaran sistem } \\
\text { peredaran darah (lebih } \\
\text { bersemangat) }\end{array}$ \\
\hline 5 & $76 \%$ & $34 \%$ & $\begin{array}{l}\text { Siswa memperhatikan setiap } \\
\text { tahapan dalam kegiatan } \\
\text { demontrasi saat pembelajaran } \\
\text { peredaran darah (lebih fokus } \\
\text { dan konsentrasi) }\end{array}$ \\
\hline 6 & $97 \%$ & $3 \%$ & $\begin{array}{l}\text { Alat peraga media analog } \\
\text { sangat tepat untuk mewakili } \\
\text { konsep materi sistem } \\
\text { peredaran darah }\end{array}$ \\
\hline 7 & $94 \%$ & $6 \%$ & $\begin{array}{l}\text { Alat peraga media analog } \\
\text { memudahkan siswa } \\
\text { memahami materi sistem } \\
\text { peredaran darah }\end{array}$ \\
\hline 8 & $25 \%$ & $85 \%$ & $\begin{array}{l}\text { Alat peraga media analog } \\
\text { tidak membuat miskonsepsi }\end{array}$ \\
\hline 9 & $98 \%$ & $2 \%$ & $\begin{array}{l}\text { Siswa merespon dengan } \\
\text { sangat baik pembelajaran } \\
\text { dengan menggunakan alat } \\
\text { peraga media analog }\end{array}$ \\
\hline 10 & $1 \%$ & $99 \%$ & $\begin{array}{l}\text { Alat peraga media analog } \\
\text { sangat bermanfaat, membantu } \\
\text { dalam memahami materi. }\end{array}$ \\
\hline
\end{tabular}

Dari hasil angket respon siswa terhadap alat peraga media analog yang berbahan baku limbah lokal Indramayu dalam pemebelajaran biologi sistem peredaran darah, yang terdiri dari 10 pernyataan dapat diinterpretasikan siswa merespon dengan baik alat peraga media 
Quagga: Jurnal Pendidikan dan Biologi

Volume 12, Nomor 1, Januari 2020, pp.31-43
p-ISSN 1907-3089, e-ISSN2651-5869

https://doi.org/10.25134/quagga.v12i1.2138 analog. Selanjutnya disempurnakan dengan sedikit revisi, dilanjutkan uji skala besar penerapannya dalam pembelajaran biologi materi sistem peredaran darah untuk melihat keefektifan media. Selain itu, dalam USK hasil posttest menunnjukkan media analog efektif terhadap hasil belajar, keaktifan siswa termasuk kategori sangat baik $(76,47 \%)$, dan motivasi termasuk kategori tinggi (69,93\%). Berdasarkan hasil tersebut, alat peraga media analog layak digunakan lebih lanjut ke uji skala besar (USB).

\section{Data Hasil Uji Skala Besar (Skala Luas) Data Hasil Belajar Kognitif}

Data hasil belajar kognitif siswa dari hasil post test yang menggunakan 5 butir soal esai dengan 3 sampel sekolah XI MIPA SMA Negeri 1 Sindang, XI MIPA SMA Negeri 1 Lohbener, dan XI MIPA SMA Negeri 1 Lelea yaitu diperoleh siswa yang skornya mencapai ataupun berjumlah 59 siswa atau dengan persentase $71,95 \%$ di atas nilai KKM 75,32 (konversi skor 15,06), hai ini menunjukkan bahwa media alat peraga "media analog" dari bahan baku limbah lokal Indramayu dalam penerapannya efektif terhadap hasil belajar kognitif siswa.

Setelah dilakukan pengolahan data mentah hasil belajar kognitif (post-test) diperoleh ratarata skor dan simpangan baku dari kelas sampel yang dapat dilihat pada tabel 3 sebagai berikut:

Tabel 3. Data Hasil Belajar Siswa (Post-test)

\begin{tabular}{ccccc}
\hline Kelas & $\begin{array}{c}\text { Jumlah } \\
\text { Siswa }\end{array}$ & $\begin{array}{c}\text { Rata- } \\
\text { rata } \\
\text { skor }\end{array}$ & Varians & $\begin{array}{c}\text { Simpangan } \\
\text { Baku } \\
\text { (Standar } \\
\text { deviasi) }\end{array}$ \\
\hline Sampel & 82 & 15.96 & 6,45 & 2,54 \\
\hline
\end{tabular}

Keterangan:

rata-rata skor dan simpangan baku akan digunakan dalam perhitungan uji normalitas data dan uji hipotesis penelitian.

Berdasarkan tabel diatas dapat diketahui bahwa rata-rata skor hasil belajar siswa yaitu 15,96 kemudian untuk simpangan baku (standar deviasi) yaitu sebesar 2,54. Selanjutkan uji t untuk melihat keefektifan media pembelajaran alat peraga "media analog" terhadap hasil belajar kognitif siswapada materi peredaran darah, maka dilakukan.

\section{1) Uji Prasyarat Analisis}

Setelah diperoleh rata-rata skor dan standar deviasi, langkah selanjutnya yaitu menguji normalitas data hasil belajar siswa kelas sampel. Dalam penelitian ini, diperoleh hasil uji normalitas sebagai berikut:

Tabel 4. Data Hasil Uji Normalitas

\begin{tabular}{cccc}
\hline Kelas & $\boldsymbol{x}_{\text {hitung }}^{\mathbf{2}}$ & $\boldsymbol{x}_{\text {tabel }}^{\mathbf{2}}$ & Keterangan \\
\hline Sampel & 3,413 & 7,815 & $\begin{array}{c}\text { Data Berdistribusi } \\
\text { Normal }\end{array}$ \\
\hline
\end{tabular}

Berdasarkan dari tabel di atas menunjukkan bahwa data pada kelas sampel diperoleh $x_{\text {hitung }}^{2}$ $=3,413$ dan $x_{\text {tabel }}^{2}=7,815$, dengan taraf signifikan $(\alpha) 0,05$ dan derajat kebebasan $\mathrm{dk}=k$ $-3=6-3=3$. Karena $x_{\text {hitung }}^{2}<x_{\text {tabel }}^{2}$, maka data (skor) hasil belajar siswa kelas sampel berdistribusi normal.

2) Uji t

Setelah datahasil tes berdistribusi normal, selanjutnya dilakukan uji-t ( $\mathrm{t}_{\text {hitung }}$ satu sampel), didapatkan data hasil belajar kognitif siswa sebagai berikut:

Tabel 5. Data Hasil Uji t

\begin{tabular}{cccccccc}
\hline Kelas & $\begin{array}{c}\text { Jumlah } \\
\text { siswa } \\
(\mathrm{n})\end{array}$ & $\begin{array}{c}\text { Skor } \\
\text { ideal }\end{array}$ & $\begin{array}{c}\text { Rata- } \\
\text { rata } \\
\text { skor }\end{array}$ & KKM & $\mathrm{S}$ & $\mathrm{t}_{\text {hitung }}$ & $\mathrm{t}_{\text {tabel }}$ \\
\hline Sampel & 82 & 20 & 15.96 & $\begin{array}{c}75,32 \\
\text { (skor } \\
15,06)\end{array}$ & 2,54 & 3,75 & 1,671 \\
\hline
\end{tabular}

Dari hasil tabel 5 diatas bahwa penerapan alat peraga media analog dalam pembelajaran biologi materi sistem peredaran darah efektif terhadap hasil belajar kognitif siswa.

\section{Data Hasil Keaktifan Siswa}

Hasil penelitian ini mendeskripsikan data keaktifan belajar siswa yang diperoleh dari hasil pengamatan lembar observasi yang dilakukan oleh tiga observer selama proses kegiatan pembelajaran yang dilakukan $2 \times 45$ menit jam pelajaran yang memanfaatkan limbah pesisir sebagi media analog pada pembelajaran sistem peredaran darah di SMA. Kegiatan pengamatan keaktifan belajar ini dilakukan pada siswa kelas XI MIPA SMA Negeri 1 Sindang, XI MIPA SMA Negeri 1 Lohbener, dan XI MIPA SMA Negeri 1 Lelea, yang terpilih sebagai kelas sampel. Data yang sudah diperoleh akan diolah dan dianalisis 
menggunakan statistik deskriptif yaitu dengan mendeskripsikan atau menggambarkan persentase (\%) keaktifan siswa pada setiap indkator dari masing-masing sekolah sampel, yang dapat dilihat pada tabel 6 . sebagai berikut:

Tabel 6. Persentase Rata-Rata Keaktifan Siswa dari Tiga Sekolah Sampel

\begin{tabular}{lcccc}
\multicolumn{4}{c}{ Nama } \\
$\begin{array}{c}\text { Sekolah } \\
\text { Skor }\end{array}$ & $\begin{array}{c}\text { Skor } \\
\text { Total }\end{array}$ & $\begin{array}{c}\text { Skeal } \\
\text { Id }\end{array}$ & $\begin{array}{c}\text { Kategori } \\
\text { Keaktifan } \\
\text { Belajar } \\
\text { Siswa }\end{array}$ \\
\hline $\begin{array}{l}\text { SMAN 1 } \\
\text { Sindang } \\
\begin{array}{l}\text { SMAN 1 } \\
\text { Lohbener }\end{array}\end{array}$ & 1232 & 1560 & 78.97 & $\begin{array}{c}\text { Sangat } \\
\text { Baik }\end{array}$ \\
$\begin{array}{l}\text { SMAN 1 } \\
\text { Lelea } \\
\text { Rata-rata }\end{array}$ & 977 & 1352 & 72.26 & Baik \\
\hline
\end{tabular}

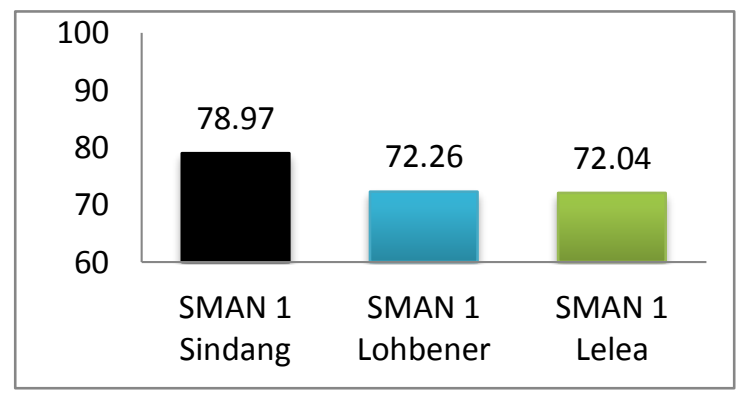

Gambar 1. Presentase rata-rata Keaktifan Siswa pada Tiga Kelas Sampel

Berdasarkan tabel 6 dan gambar 1 diatas, dapat diketahui bahwa persentase rata-rata yang keaktifan belajar siswa dengan pemanfaatan limbah pesisir sebagai media analog pada pembeajaran sistem peredaran darah di kelas XI MIPA SMA Negeri 1 Sindang dengan kategori sangat baik, sedangkan pada kelas XI SMA Negeri 1 Lohbener dan SMA Negeri 1 Lelea yaitu dengan kategori baik. Dengan demikian persentase rata-rata keaktifan belajar siswa termasuk kedalam kategori baik.Artinya pemanfaatan limbah pesisir sebagai media media analod pada pembelajaran sistem peredaran darah dapat mengaktifkan belajar siswa dengan baik.

\section{Data Hasil Motivasi Belajar Siswa}

Hasil penelitian mendeskripsikan data motivasi belajar siswa dalam penelitian ini diperoleh dari hasil penskoran angket motivasi belajar siswa yang diberikan dan diisi oleh siswa setelah proses pembelajaran berakhir. Setelah dilakukan penskoran dan diperoleh data, kemudian data diolah dan dianalisis untuk diinterpretasikan.Penilaian menggunakan skala likert. Berikut tingkat motivasi belajar siswa yang menggunakan media analogdisajikan pada Tabel 7 sebagai berikut:

Tabel 7.Tingkat Motivasi Belajar Siswa

\begin{tabular}{lcccc}
\hline Nama Sekolah & $\begin{array}{c}\text { Skor } \\
\text { Total }\end{array}$ & $\begin{array}{c}\text { Skor } \\
\text { Ideal }\end{array}$ & $\%$ & $\begin{array}{c}\text { Kategori } \\
\text { Motivasi } \\
\text { Belajar Siswa }\end{array}$ \\
\hline SMAN 1 Sindang & 1743 & 2400 & 72.63 & Tinggi \\
SMAN 1 Lohbener & 1418 & 2080 & 68.17 & Sedang \\
SMAN 1 Lelea & 1373 & 2080 & 66.01 & Sedang \\
& 4534 & 6560 & 69.12 & Tinggi \\
\hline
\end{tabular}

Berdasarkan tabel 7, menunjukkan bahwa hasil gambaran motivasi belajar siswa menggunakan media analog sistem peredaran darah memiliki tingkat motivasi yang berbeda tiap sekolah, hal ini terlihat bahwa setelah pembelajaran menggunakan media analog terdapat kategori tinggi untuk SMAN 1 Sindang dan kategori sedang untuk dua sekolah lainnya.

\section{Hasil Motivasi Belajar Siswa Setiap Indikator}

Adapun hasil presentase motivasi belajar siswa dari setiap indikator disajikan pada Tabel 8 sebagai berikut:

Tabel 8. Motivasi Belajar Siswa Tiap Indikator

\begin{tabular}{|c|c|c|c|c|c|c|c|}
\hline \multirow{2}{*}{ Indikator } & \multicolumn{2}{|c|}{$\begin{array}{l}\text { SMAN } 1 \\
\text { Sindang }\end{array}$} & \multicolumn{2}{|c|}{$\begin{array}{c}\text { SMAN } 1 \\
\text { Lohbener }\end{array}$} & \multicolumn{2}{|c|}{ SMAN 1 Lelea } & \multirow[t]{2}{*}{$\begin{array}{c}\text { Rata- } \\
\text { rata }(\%)\end{array}$} \\
\hline & $(\%)$ & Kriteria & $(\%)$ & Kriteria & $(\%)$ & $\begin{array}{c}\text { Kriteri } \\
\mathbf{a}\end{array}$ & \\
\hline $\begin{array}{l}\text { Tekun } \\
\text { menghadapi } \\
\text { tugas. (rajin dan } \\
\text { bersungguh- } \\
\text { sungguh) }\end{array}$ & 75,63 & Tinggi & 67,55 & Sedang & 69,95 & Tinggi & 71,04 \\
\hline $\begin{array}{l}\text { Ulet } \\
\text { menghadapi } \\
\text { kesulitan (tidak } \\
\text { mudah putus } \\
\text { asa) }\end{array}$ & 73,13 & Tinggi & 63,46 & Sedang & 69,71 & Tinggi & 68,77 \\
\hline $\begin{array}{l}\text { Menunjukan } \\
\text { minat terhadap } \\
\text { bermacam- } \\
\text { macam } \\
\text { masalah.(keingi } \\
\text { nan) }\end{array}$ & 76,67 & Tinggi & 70,51 & Tinggi & 73,08 & Tinggi & 73,42 \\
\hline $\begin{array}{l}\text { Lebih senang } \\
\text { bekerja mandiri } \\
\text { (tidak bergntung }\end{array}$ & 62,08 & Sedang & 63,94 & Sedang & 67,79 & Sedang & 64,60 \\
\hline
\end{tabular}




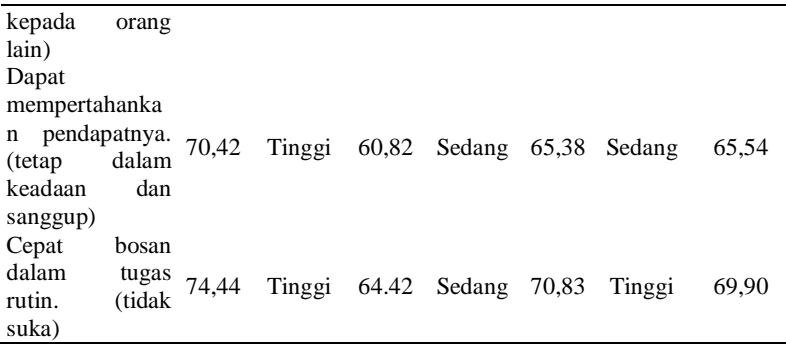

Berdasarkan Tabel, menunjukan gambaran motivasi belajar siswa pada masingmasingsekolah dari 6 indikator yaitu indikator 1 memperoleh skor persentase $71,04 \%$ termasuk dalam kategori "tinggi", indikator 2 memperoleh skor persentase $68,77 \%$ termasuk dalam kategori "tinggi", indikator 3 memperoleh skor persentase $73,42 \%$ termasuk dalam kategori "tinggi", indikator 4 memperoleh skor persentase $64,60 \%$ termasuk dalam kategori "tinggi", indikator 5 memperoleh skor persentase $65,54 \%$ termasuk dalam kategori "sedang", dan indikator 6 memperoleh skor persentase $69,90 \%$ termasuk dalam kategori "tinggi'.

\section{Pembahasan}

\section{Hasil Validasi Ahli dan Uji Skala Kecil}

Berdasarkan tabel 2 dari hasil validasi ahli produk yang mencakup empat (4) penilaian aspek yaitu aspek "kesesuaian" memperoleh dengan kategori sangat baik. Sedangkan aspek "kemudahan" dalam kategori cukup baik, sehingga perlu dilakukan perbaikan media/ sedikit revisi. Untuk aspek "kemenarikan" termasuk kategori sangat baik. Dan aspek "kebermanfaatan" kategori sangat baik. Berdasarkan hasil tersebut, alat peraga media analog layak digunakan lebih lanjut dalam pembelajaran biologi dengan sedikit revisi, hal ini bahwa alat peraga media analog berbahan baku limbah lokal Indramayu yang diterapkan dalam pembelajaran biologi materi sistem peredaran darah pada manusia untuk meliahat efektivitasnya, hal ini sesuai dengan hasil penelitian terdahulu yang menyatakan bahwa hasil validasi ahli menentukan kelayakan produk pengembangan (Angko, 2013).

Kemudian sejalan pula dengan Anggraini, 2016 menyatakan bahwa hasil validator ahli materi mendukung kelayakan bahwa alat peraga media analog dapat mewakili konsep materi peredaran darah.
Berdasarkan tabel 3 dari hasil intrepretasi respon siswa pada uji lapangan skala kecil yang mencakup 10 pernyatan yaitu alat peraga media analog berbahan baku limbah lokal indramayu pada pembelajaran biologi materi sistem peredaran darah mendapat respon sangat baik ari siswa hal ini menunjukkan bahwa alata peraga media analog layak digunakan karena dapat mewakili, menggambarkan mekanikasi konsep materi sistem peredaran sehingga dapat mendukung proses pembelajaran sejalan dengan pendapat (Fransina T.N, dan Theodora S.N.M, 2018), bahwa alat peraga sangat membantu dalam keberhasilan pembelajaran.

Efektivitas alat peraga media analog berbahan baku limbah lokal indramayu terhadap hasil belajar biologi siswa

Hasil belajar kognitif siswa

Dari hasil uji skala besar penerapan alat peraga media analog berbahan baku limbah lokal Indramayu pada pembelajaran materi sistem peredaran darah menunjukkan hasil belajar kognitif siswa cukup baik karena dari 82 siswa terdapat 56 siswa yang mencapai KKM. Didukung berdasarkan tabel 5 dan hasil uji t pada tabel 7 bahwa alat peraga media analog berbahan baku limbah lokal indramayu efektif dalam pembelajaran biologi materi sistem peredaran darah. Hal ini menunjukkan bahwa dalam suatu proses pembelajaran yang baik, tentu akan efektif terhadap hasil belajarnya dan tujuan pembelajaran tercapai. Dalam penelitian ini, penggunaan media alat peraga "media analog" efektif terhadap hasil belajar siswa pada materi peredaran darah.Pembelajaran yang efektif adalah pembelajaran yang menyediakan kesempatan kepada siswa untuk dapat belajar sendiri atau melakukan aktivitas sendiri. Hal tersebut sejalan dengan hasil penelitian yang menyatakan bahwa pembelajaran dikatakan efektif jika peserta didik mengalami berbagai pengalaman baru (new experience) dan perilakunya berubah menuju titik akumulasi kompetensi yang diharapkan. Hal ini, sesuai dengan hasil pengamatan yang dilakukan oleh peneliti di kelas sampel pada saat KBM (kegiatan belajar mengajar), penggunaan media alat peraga tiga "media analog" menjadikan siswa lebih cepat mudah memahami konsep/ 
materi sistem peredaran darah manusia yang bersifat abstrak menjadi konkrit.

Hal tersebut dapat dilihat dari hasil tes belajar siswa, dari 82 siswa yang hadir dalam pembelajaran (di kelas sampel/ kelas eksperimen) terdapat siswa yang skornya mencapai dan di atas KKM, yaituber jumlah 59 siswa atau 71,95\%. Hasil belajar kognitif (posttest) siswa menunjukkan bahwa siswa mampu mengerjakannya dengan baik semua soal-soal yang diberikan saat posttest. Soal-soal tersebut dibuat mengacu atau berdasarkan pada indikator taksonomi bloom revisi Anderson dan Kartwohl (Suharsimi, 2012:129). Jenjang yang diukur yaitu C3 (menerapkan), C4 (menganalisis), dan (mengevaluasi).Keberhasilan siswa dalam menjawab soal tes hasil belajar tersebut dikarenakan siswa mampu mengingat dengan baik hampir semua konsep yang terdapat pada media alat peraga "media analog" tersebut. Hal ini, sesuai dengan pendapat Widiatmoko (2012:51) yang mengatakan bahwa, pembelajaran menggunakan alat peraga berarti mengoptimalkan fungsi seluruh pancaindra siswa untuk meningkatkan efektivitas siswa belajar dengan cara mendengar, melihat, meraba, dan menggunakan pikirannya secara logis dan realistis. Hal tersebut sesuai dengan aktivitas siswa saat mengikuti kegiatan belajar mengajar, sebagian besar siswa ikut merakit dan mendemonstrasikan media alat peraga "media analog" dikarenakan kemungkinan siswa baru pertama kali melihat media alat peraga "media analog" tentang sistem peredaran darah yang menyerupai jalan, mobil, orang-orangan, dll (analogi).

Dengan demikian dapat dikatakan bahwa media alat peraga tiga dimensi merupakan wahana penyalur pesan atau informasi belajar yang baik. Hal tersebut dikarenakan siswa mendapatkan gambaran yang konkrit tentang materi yang diajarkan melalui media alat peraga "media analog" yang berupa tiruan peredaran darah sebagai alat bantu demonstrasi yang digunakan dan siswa juga mendapat pemahaman lebih dengan mempraktekan sendiri secara langsung materi yang diajarkan.

Penggunaan media alat peraga tiga dimensi ini juga dapat terlihat dari aktivitas siswa dalam kegiatan belajar mengajar.Seluruh siswa menjadi fokus terhadap pembelajaran karena perhatian siswa tertuju pada media pembelajaran, sehingga siswa dapat menangkap semua materi yang telah diajarkan. Berdasarkan pengamatan saat proses belajar mengajar dikelas (sampel/ eksperimen), keefektifan media alat peraga "media analog" tersebut kemungkinan disebabkan oleh perhatian, motivasi, dan minat siswa yang sangat positif, karena memperoleh pengalaman baru dalam pembelajaran biologi peredaran darah manusia. Selain itu, siswa mau mencoba menggunakan media alat peraga (kegiatan demonstrasi) yang baru sehingga materi abstrak menjadi konkrit. Berdasarkan hal tersebut, penggunaan media alat peraga "media analog" dari bahan baku limbah lokal Indramayu efektif terhadap kegiatan belajar mengajar. Hal tersebut sejalan dengan Hartati (2010:128) yang mangatakan bahwa penggunaan alat peraga banyak sekali manfaatnya diantaranya untuk mengurangi terjadinya verbalisme, memperbesar minat dan perhatian siswa untuk belajar, memberikan pengalaman yang nyata untuk dapat menumbuhkan kegiatan berusaha sendiri pada tiap diri siswa, menumbuhkan pemikiran yang teratur dan berkesinambungan, memberikan pengalaman yang tidak mudah diperoleh dengan cara lain.

Dengan Demikian, dapat disimpulkan bahwa hasil penelitian yang telah dilakukan oleh penulis sesuai dengan teori-teori media alat peraga tiga dimensi dan penelitianpenelitian terdahulu yang relevan. Sehingga dapat disimpulkan bahwa penggunaan media alat peraga "media analog" dari bahan baku limbah lokal Indramayu pada materi peredaran darah efektif terhadap hasil belajar siswa SMA pada materi peredaran darah.

\section{Keaktifan Belajar Siswa}

Keaktifan belajar siswa dalam penelitian ini yaitu pemanfaatan limbah pesisir sebagai media analog pada pembelajaran sistem peredaran darah, dari hasil penelitian pada (tabel 1), bahwa dari ketiga sekolah sampel kelas XI SMA Negeri 1 Sindang, SMA Negeri 1 Lohbener, dan SMA Negeri 1 Lelea, masingmasing memiliki keaktifan siswa yang berbedabeda pada setiap indikatornya. Kategori 
keaktifan belajar siswa terbagi menjadi empat kategori yaitu sangat baik, baik, cukup dan kurang dengan indikator yaitu: visual activities, listening activities, mental activities, oral activities, dan writing activities.

Pada indikator 1 keaktifan belajar siswa yaitu visual activities, dari kelas XI MIPA SMA Negeri 1 Sindang memiliki persentase tertinggi yaitu 90\% dengan kategori sangat baik, sedangkan pada kelas XI MIPA SMA Negeri 1 Lelea juga memperoleh kategori sangat baik tetapi hanya memiliki persentase $88,46 \%$, namun dari kelas XI MIPA SMA Negeri 1 Lohbener hanya memperoleh kategori baik dengan persentase sebesar $73,56 \%$. Adapun dalam kegiatan belajar mengajarnya siswa memperhatikan kegiatan demonstrasi proses penyusunan media analog pada saat pembelajaran sistem perdaran darah. Pada hakekatnya keaktifan belajar terjadi dan terdapat pada semua perbuatan belajar, tetapi kadarnya yang berbeda-beda tergantung pada jenis kegiatannya, materi yang dipelajari dan tujuan yang hendak dicapai.Kegiatan belajar mengajar dengan pemanfaatan limbah pesisir sebagai media analog pada pembelajaran sistem peredaran darah membuat siswa tertarik untuk melihat setiap tahapan dan penjelasan yang diberikan.Oleh karena itu siswa mendapatkan pengalaman belajarnya sehingga dapat memaksimalkan visual activiti. Hal tersebut diperkuat dengan pendapat Winata putra (2007:55) bahwa rata-rata informasi yang seseorang peroleh melalui indera adalah 75\% melalui penglihatan (visual). Kemudian, diperkuatdengan pendapat Suwardi dkk (2014: 297) bahwa pengajaran dengan menggunakan alat peraga akan dapat memperbesar perhatian siswa terhadap pengajaran yang dilangsungkan, karena mereka terlibat aktif dalam pengajaran yang dilaksanakan.

Indikator keaktifan belajar yang kedua yaitu listening activities, siswa secara keseluruhan dari ketiga kelas sampel memperoleh kategori sangat baik. Kelas XI MIPA SMA Negeri 1 Sindang memiliki persentase $84,72 \%$, SMA Negeri 1 Lohbener memiliki persentase $81,41 \%$, dan SMA Negeri 1 Lelea memiliki persentase $85,58 \%$ tertinggi. Kegiatan listening activities yang dimaksud dalam aktivitas ini yaitu mendengarkan penjelasan guru saat menyampaikan materi, mendengarkan teman kelas saat menyampaikan pendapat, dan mendengarkan penjelasan teman sekelas saat sedang mendemonstrasikan media analog dalampembelajaran sistem peredaran darah, pada saat proses belajar mengajar berlangsung, seluruh siswa mendengarkan dengan baik penjelasan yang diberikan oleh guru maupun temannya sendiri. Hal tersebut sesuai Harold Spears menyatakan learning is to observe, to read, to imitate, to try something themselves, to listen, to follow direction (Belajar adalah mengamati, membaca, meniru, mencoba sesuatu, mendengar dan mengikuti) diikuti dengan penelitian yang telah dilakukan oleh Jonkenedy (2017:595) yang mengatakan bahwa melalui penggunaan media tiga dimensi pada kegiatan pembelajaran, siswa aktif secara visual, lisan, mendengarkan dan menulis. Pembelajaran aktif merupakan pendekatan pembelajaran yang lebih banyak melibatkan aktifitas siswa dalam mengakses berbagai informasi dan pengetahuan untuk dibahas dan dikaji dalam proses pembelajaran dikelas, sehingga mereka dapat meningkatkan pemahaman dan kompetensinya.

Indikator keaktifan belajar yang ketiga yaitu oral activities. Kategori keaktifan belajar indikator oral activities termasuk kedalam kategori baik dari ketiga kelas sampel yaitu pada kelas XI SMA Negeri 1 Sindang memperoleh persentase 72,92 tertinggi, SMA Negeri 1 Lohbener dengan persentase 62,26, dan SMA Negeri 1 Lelea medapat persentase sebesar 56, 97 Hal ini disebabkan, masih adanya siswa yang kurang percaya diri dan takut salah untuk menyampaikan pendapat maupun untuk bertanya pada saat proses kegiatan belajar mengajar berlangsung, dikarenakan siswa terbiasa dengan belajar satu arah yaitu penyampaian pesan materi dari guru ke siswa saja, hanya sebagian besar siswa yang sudah berani dan mampu menyampaikan pendapat maupun bertanya pada saat pembelajaran materi peredara darah. Meskipun guru sudah mempersilahkan semua siswa untuk bertanya atau menyampaikan pendapat. Pembelajaran akan lebih bermakna jika siswa diberi kesempatan untuk berpartisipasi dalam 
Quagga: Jurnal Pendidikan dan Biologi

Volume 12, Nomor 1, Januari 2020, pp.31-43
p-ISSN 1907-3089, e-ISSN2651-5869

https://doi.org/10.25134/quagga.v12i1.2138 berbagai aktivitas kegiatan pembelajaran. Sejalan pula dengan Martinis Yamin (2007: 77) menyebutkan, keaktifan siswa dalam proses pembelajaran dapat merangsang dan mengembangkan bakat yang dimilikinya, berfikir kritis, dan dapat memecah permasalahan-permasalahan dalam kehidupan sehari-hari. belajar aktif merupakan fungsi interaksi antara individu dan situasi di sekitarnya yang ditentukan oleh indikator merupakan pengembangan dari kompetensi dasar. Interaksi yang terus menerus menimbulkan pengalaman-pengalaman dan keinginan untuk memahami sesuatu yang baru, yang belum dipahami, atau yang belum dialami.

Kemudian, untuk indikator keempat yaitu mental activities.Secara keseluruhan, indikator keaktifan keempat ini termasuk kedalam kategori sangat baik. Adapun persentase yang diperoleh dari kelas XI MIPA SMA Negeri 1 Sindang sebesar $85,42 \%$ tertinggi, SMA Negeri 1 Lohbener 80,77\% dan SMA Negeri 1 Lelea $79,33 \%$. Pada indikator mental activities berdasarkan hasil pengamatan saat proses belajar mengajar dengan pemanfaatan limbah pesisir sebagai media analog pada pembelajaran sistem peredaran darah, keaktifan belajar siswa pada indikator mental activities terlihat pada saat siswa menyusun media, semua siswa antusias untuk berpartisipasi dalam menyusun media tersebut, semua bergantian dan saling bantu. Selain itu, siswa juga berani dalam melakukan demonstrasi sistem peredaran darah kecil dan sistem peredaran darah besar. Hal tersebut didukung dengan penelitian yang dilakukan oleh Annisah (2014:5) bahwa kelebihan media analog sebagai alat peraga yaitu membuat peserta didik lebih aktif dalam melakukan kegiatan belajar seperti mengamati, melakukan, mendemonstrasikan dan sebagainya. Didukung Sardiman (2009:100) berpendapat bahwa "Aktifitas di sini yang baik ialah yang bersifat fisik dan non fisik atau mental dalam kegiatan pembelajaran, kedua aktifitas tersebut harus saling terkait, keterkaitan keduanya akan menumbuhkan keaktifan yang optimal.

Indikator keaktifan belajar siswa yang terakhir yaitu writing activities.Secara keseluruhan, indikator keaktifan kelima ini termasuk kedalam kategori baik. Adapun persentase yang diperoleh dari kelas XI MIPA SMA Negeri 1 Sindang sebesar $65,00 \%$, SMA Negeri 1 Lohbener 68,75 tertinggi dan SMA Negeri 1 Lelea 58,17. Hal ini terlihat saat proses pembelajaran berlangsung, semua siswa mencatat materi yang diajarkan dengan skor keaktifan belajar yang berbeda-beda pada setiap siswanya. Hal tersebut dikarenakan pemanfaatan limbah pesisir sebagai media analog pada pembelajaran sistem peredaran darah yang digunakan membuat siswa tertarik mengaitkan pemahaman materi ajar dengan pengalamannya. Hal ini diperkuat oleh pernyataan Rousseau (Sardiman, 2007: 96) yang mengatakan bahwa segala pengetahuan itu harus diperoleh dengan pengamatan sendiri, pengalaman sendiri, penyelidikan sendiri, dengan bekerja sendiri, dengan fasilitas sendiri yang diciptakan sendiri baik secara rohani maupun teknis.

\section{Persentase Rata-rata Keaktifan Siswa}

Berdasarkan uraian pada tabel 2 dan gambar 2, dapat digambarkan bahwa persentase keaktifan belajar siswa keseluruhan memperoleh kategori baik. Adapun dari kelas XI MIPA SMA Negeri 1 Sindang memperoleh persentase rata-rata $78,97 \%$ dengan kategori sangat baik, SMA Negeri 1 Lohbener persentase rata-rata 72,26\%, dan SMA Negeri 1 Lelea $72,04 \%$. Pemanfaatan limbah pesisir sebagai media analog pada materi sistem sistem peredaran darah yaitu dapat mengaktifan siswa dalam belajar. Hal ini dipengaruhi oleh faktor luar dan faktor dalam.Faktor dalam seperti minat dan motivasi belajar siswa itu sendiri, sedangkan faktor luar yang meliputi karakteristik bahan pengajaran dan juga faktor pendekatan belajar yang dilakukan oleh guru.keaktifan belajar adalah suatu sistem belajar mengajar yang menekankan keaktifan peserta didik secara fisik, mental intelektual dan emosional guna memperoleh hasil belajar yang berupa perpaduan antara aspek afektif, kognitif, dan psikomotor. Keaktifan belajar siswa tidak mungkin akan tercipta bila tidak didukung dengan pembelajaran yang aktif. Keaktifan belajar itu merupakan kegiatan siswa sedangkan pembelajaran yang aktif ialah 
kegiatan guru dan siswa yang telah dirancang oleh guru pada RPP, dan ditunjang dengan pendekatan, metode, model pembelajaran, serta media pembelajaran yang membantu guru dan siswa dalam kegiatan belajar dan mengajar, oleh karena itu dapat mengakifkan belajar siswa dengan optimal.

\section{Motivasi Belajar Siswa}

Setelah mengetahui pencapaiaan penguasaan konsep siswa, pencapaian tersebut tidak terlepas dari motivasi dalam diri siswa.Hal ini sejalan dengan Anisa (2017) bahwa motivasi belajar siswa berkaitan dengan penguasaan konsep yang dimikili siswa. Adapun motivasi dalam penelitian ini yaitu motivasi intrinsik yang diambil dari penilaian lembar angket motivasi belajar siswa yang diberikan secara individu setelah pembelajaran berakhir.Berdasarkan hasil penelitian, perhitungan angket motivasi belajar dilakukan dengan penskoran pada setiap pernyataan angket motivasi belajar siswa dan tercantum pada Tabel 7 yang menunjukan presentase hasil gambaran motivasi belajar siswa setelah menggunakan media analog system peredaran darah. Motivasi belajar siswa berada pada kategori tinggi. Hal ini dikarenakan media analog system peredaran darah membuat siswa semangat dan minat untuk belajar.

Motivasi yang digambarkan dalam penelitian ini yaitu motivasi intrinsik yang diambil dari penilaian lembar angket motivasi belajar siswa yang diberikan secara individu setelah pembelajaran berakhir. Berdasarkan hasil penelitian, perhitungan angket motivasi belajar dilakukan dengan penskoran pada setiap pernyataan angket motivasi belajar siswa dan tercantum pada Tabel 7 yang menunjukan presentase hasil gambaran motivasi belajar siswa setelah menggunakan media analog, untuk lebih memperjelas tabel hasil motivasi belajar siswa setelah menggunakan media analogbisa dilihat pada tabel 2 dapat diketahui pada indikator motivasi belajar siswa I (tekun menghadapi tugas) motivasi belajar siswa cenderung tinggi, bisa dilihat tabel memperoleh rata-rata presentase sebesar $71,04 \%$, pada indikator motivasi belajar siswa II (ulet menghadapi kesulitan) motivasi belajar siswa sedang yaitu sebesar $68,77 \%$, pada indikator motivasi belajar III (minat terhadap bermacam masalah) motivasi belajar siswa cenderung tinggi yaitu sebesar $73,42 \%$, pada indikator motivasi belajar siswa IV (lebih senang bekerja mandiri) motivasi belajar siswa pada kategori sedang yaitu sebesar $64,60 \%$, pada indikator motivasi belajar V (mempertahankan pendapat) motivasi belajar siswa cenderung sedang yaitu sebesar sebesar $65,54 \%$, selanjutnya pada indikator motivasi belajar siswa VI (tidak cepat bosan dalam tugas rutin) motivasi belajar siswa cenderung tinggi yaitu sebesar 69,90\%, berdasarkan hasil tersebut rata-rata siswa memiliki motivasi tinggi dalam belajar materi sistem peredaran darah dengan menggunakan media analog. Pemakaian media pembelajaran dalam proses belajar mengejar dapat membangkitkan keinginan dan minat yang baru, membangkitkan motivasi dan rangsangan kegiatan belajar, dan bahkan membawa pengeruh-pengaruh psikologis terhadap siswa.

Kemudian jika dilihat dari indikator motivasi belajar siswa pada Tabel 2 Berdasarkan data tersebut, menunjukan gambaran motivasi belajar siswa tiap indikator pada pembelajaran sistem peredaran darah. Untuk indikator I (tekun menghadapi tugas) memperoleh persentase $71,04 \%$ dan memiliki kategori tinggi, artinya siswa mampu mengerjakan atau menyelesaikan tugas dengan baik bersungguh-sungguh serta tepat waktu dalam merangkai media dan mendemonstrasikan (presentasi). Hal tersebut terlihat pada saat kegiatan belajar siswa dapat menyelesaikan tugas merangkai media dengan tepat waktu, mempresentasikan materi system peredaran darah dengan baik, selalu memperhatikan dan mencatat materi, dari aktivitas belajar tersebut memperlihatkan siswa tekun dalam proses belajar. Hal ini senada dengan penelitian Retno. D., dkk. (2018) yang mengatakan penggunaan media gambar dan alat peraga membuat siswa lebih tertarik dan terdorong untuk mengikuti proses pembelajaran yang berlangsung.

Indikator II (ulet menghadapi kesulitan belajar) memperoleh persentase $68,77 \%$ dan memiliki kategori sedang, artinya siswa tidak lekas putus asa dalam menghadapi kesulitan belajar dan siswa bertanggung jawab terhadap 
keberhasilan melaksanakan kegiatan belajar. Hal tersebut terlihat dari proses pembelajaran dikelas siswa tidak kesulitan dalam merangkai media pembelajaran dan ketika ada pertanyaan beberapa siswa dapat menjawab. Hal tersebut didukung oleh pernyataan dari Encyclopedia of Educational Reaserch dalam yang mengatakan manfaat media salah satunya memberikan pengalaman nyata yang dapat menumbuhkan kegiatan berusaha sendiri di kalangan siswa.

Indikator III (menunjukan minat terhadap bermacam masalah) memperoleh persentase $73,42 \%$ dan memiliki kategori tinggi, artinya siswa mampu menunjukan minat atau keinginan kuat dalam belajar dan menyelesaikan masalah, seperti yang terlihat pada saat proses pembelajaran menggunakan media alat peraga, siswa selalu memperhatikan dan mendengarkan penjelasan guru atau teman dalam setiap tahapan-tahapan demonstrasi sistem peredaran darah dan ketika mengalami kesulitan dalam memahami materi siswa selalu bertanya. Seperti yang dikatakan dalam penelitian Nurhadi (2017) Jika siswa sudah memiliki minat yang tinggi siswa akan lebih melibatkan dirinya untuk belajar sehingga suasana kelas yang tercipta menjadi aktif dan siswa merasa antusias dalam mengikuti kegiatan belajar. Lebih lanjut Sudjana (1992) mengatakan bahwa menumbuhkan minat belajar siswa karena pelajaran menjadi lebih menarik, memperjelas makna bahan pelajaran sehingga siswa lebih mudah memahaminya, metode mengajar akan lebih bervariasi sehingga siswa tidak akan mudah bosan, membuat lebih aktif melakukan kegiatan belajar seperti: mengamati, melakukan, mendemonstrasikan dan sebagainya.

Indikator IV (lebih senang bekerja mandiri) memperoleh persentase $64,60 \%$ dan memiliki kategori sedang, menggambarkan siswa mampu bekerja mandiri tidak bergantung pada orang lain, seperti pada saat merangkai media alat peraga, siswa mampu mengerjakan secara mandiri tanpa melihat atau sesekali bertanya pada teman, artinya tanpa harus disuruh ia akan mengerjakan apa yang menjadi tugasnya seperti halnya dapat merangkai media dan menjawab soal posttest secara mandiri. Hal tesebut sejalan dengan pendapat beberapa ahli dalam Azhar
(2017) yang mengatakan bahwa media pembelajaran dapat meningkatkan dan mengarahkan perhatian anak sehingga dapat menimbulkan motivasi belajar, interaksi yang lebih langsung antara siswa dan lingkungannya, dan kemungkinan siswa untuk belajar sendirisendiri sesuai dengan kemampuan dan minatnya.

Indikator $\mathrm{V}$ (dapat mempertahankan pendapatnya) memperoleh persentase $65,54 \%$ dan memiliki kategori sedang, menggambarkan siswa masih belum maksimal dalam memberikan pendapat atau tanggapan, hal tersebut dapat terlihat pada saat kegiatan demonstrasi dengan menggunakan media alat peraga, ketika guru meminta pendapat siswa mengenai materi yang yang disampaikan temannya, hanya sebagian siswa saja yang dapat memberikan pendapat atau tanggapan (Dally, 2017). sejalan pula dengan Nurhadi (2017) dalam penelitiannya mengemukakan mempertahankan pendapatnya siswa memperoleh tingkat kategori rendah menujukan bahwa siswa masih belum termotivasi pada pembelajaran biologi.

Indikator VI (cepat bosan dalam tugas rutin) memperoleh persentase $69,90 \%$ dan memiliki kategori tinggi, hal tersebut menggambarkan siswa tidak merasa bosan atau jenuh dengan pembelajaran menggunakan media analog yang berlangsung dan sangat termotivasi (menarik siswa untuk selalu memperhatikan dan aktif berpartisipasi dalam proses tahapan kegiatan demonstrasi). Menurut Sudjana \& Rivai (1992) dalam azhar (2017:28) mengemukakan bahwa dengan menggunakan media, metode belajar akan lebih bervariasi tidak semata-mata komunikasi verbal melalui penuturan kata-kata oleh guru sehingga siswa tidak bosan dan guru tidak kehabisan tenaga.

Berdasarkan pemaparan diatas dapat disimpulkan, untuk gambaran motivasi belajar siswa dari keenam indikator terdapat satu indikator yang memiliki presentase tertinggi yaitu pada indikator III (Menunjukan minat terhadap bermacam-macam masalah (keinginan)) dengan presentase $73,42 \%$, hal tersebut menunjukan bahwa media analog dapat meningkatkan motivasi belajar dan minat belajar siswa serta membawa pengaruh 
Quagga: Jurnal Pendidikan dan Biologi

Volume 12, Nomor 1, Januari 2020, pp.31-43
p-ISSN 1907-3089, e-ISSN2651-5869

https://doi.org/10.25134/quagga.v12i1.2138 psikologis siswa untuk belajar dengan nyaman sehingga siswa memiliki minat dalam belajar system peredaran darah.. Sedangkan gambaran motivasi terendah terdapat pada indikator $\mathrm{V}$ (Lebih senang bekerja mandiri (tidak bergntung kepada orang lain)) dengan presentase $64,60 \%$, hal tersebut menunjukan masih terdapat beberapa siswa dalam sekolah yang belum termotivasi untuk belajar mandiri.

\section{SIMPULAN}

Berdasarkan hasil penelitian eksplorasi limbah lokal Indramayu sebagai bahan baku alat peraga media analog dan efektivitasnya terhadap hasil belajar biologi siwa adalah berdasarkan hasil validasi produk oleh ahli yang terdiri dari empat (4) aspek yaitu aspek "kesesuaian" memperoleh dengan kategori sangat baik, aspek "kemudahan" dalam kategori cukup baik, sehingga perlu dilakukan perbaikan media/ sedikit revisi, aspek "kemenarikan" termasuk kategori sangat baik, dan aspek "kebermanfaatan" kategori sangat baik. Berdasarkan hasil tersebut, alat peraga media analog layak digunakan lebih lanjut dalam pembelajaran biologi.

Berdasarkan hasil efektivitas hasil belajar kognitif siswa dilihat dari hasil uji $t$ memperoleh skor rata-rata hasil belajar siswa $15,96 \%$ dan siswa yang lulus KKM sebesar $71,59 \%$. Kemudian dari hasil keaktifan siswa menunjukkan rata-rata persentase $74,65 \%$ kategori sangat baik di, sedangkan hasil motivasi belajar siswa menunjukkan rata-rata persentase sebesar $69,12 \%$ dengan kategori tinggi.

\section{UCAPAN TERIMA KASIH}

Ucapan terimakasih kami tim penelitian dosen pemula (PDP) kepada pihak-pihak yang sudah membantu penelitian ini diantaranya, KEMERISTEKDIKTI, LPPM Universitas Wiralodra, KCD Pendidikan Wilayah IX Provinsi Jawa Barat, dan sekolah menengah atas di kabupaten Indramayu, khsusnya sekolah sampel yang terpilih yaitu SMA Negeri 1 Sindang, SMA Negeri 1 Lohbener, dan SMA Negeri 1 Lelea, Serta Semua pihak yang telah memberikan Ide kreatif, Gagasan, pemikiran, semangat dan do'a. Semoga Allah memberikan balasan yang terbaik kepada semuanya, Aamiin.

\section{REFERENSI}

Anggraini Feranita. 2016. Pengembangan Alat Peraga Sistem Pernapasan Manusia Berbasis Barang Bekas Pada Siswa SMP $N 1$ Bandar Lampung. Jurnal: Bandar Lampung. FKIP Biologi Lampung.Vol.1, No.1:20-21.

Angko Nancy. 2013. Pengembangan Bahan Ajar Dengan Model ADDIE Untuk Mata Pelajaran Matematika Kelas 5 SDS Mawar Sharon Surabaya. Jurnal : Surabaya. Universitas Negeri Surabaya. Vol.VII, No. 01:18-19.

Annisah, S. 2014. Alat peraga Pembelajaran Matematika. Jurnal Tarbiyah, 11(1)

Arsyad, A. 2017. Media Pembelajaran (Ed.revisi, cetakan ke-20). Jakarta: Raja Grafindo Persada

Dally, S. 2017. Pengaruh Motivasi, Disiplin, dan Kompetensi terhadap Kinerja Pegawai. Jurnal Publik 2 (11). 269-278.

Fransina T.N, \& Theodora S.N.M. 2018. Pengembangan Audio Visual dan Alat Peraga dalam Meningkatkan Pemahaman Konsep dan Pemecahan Masalah. Program Studi Pendidikan Biologi, Universitas Kristen Artha Wacana-Kupang

Hanafi. 2017. Konsep Penelitian $R \& D$ dalam Bidang Pendidikan. Jurnal saintifika Islamica. 2 (4): 129-150

Hartati. 2010. Pengembangan Alat Peraga Gaya Gesek Untuk Meningkatkan Keterampilan Berpikir Kritis Siswa SMA. Jurnal Pendidikan Fisika Indonesia. 6 (2) :128-132.

Jonkenedy. 2017. Penggunaan Media Tiga Dimensi Untuk Meningkatkan Keaktifan Siswa Dalam Pembelajaran IPA. Jurnal Pendidikan Guru Sekolah Dasar Edisi 6 Tahun ke-6

Nurmaningsih, dkk. 2013. Pengembangan Media Animasi Biologi dan Efektivitasnya terhadap Minat dan serta Hasil Belajar siswa SMA Negeri 7 Mataram. Jurnal Pendidikan Matematika dan Sains. 1 (1) 
Quagga: Jurnal Pendidikan dan Biologi

Volume 12, Nomor 1, Januari 2020, pp.31-43
p-ISSN 1907-3089, e-ISSN2651-5869

https://doi.org/10.25134/quagga.v12i1.2138

Retno, D, dkk. 2018. Pengaruh Strategi Pembelajaran Dan Motivasi Belajar Terhadap Higher Order Thinking Skills (HOTS) Dalam Pembelajaran IPA Siswa Kelas IV Sekolah Dasar. Jurnal Tunas Bangsa 2 (5). STKIP BBG.

Suharsimi, Arikunto. 2012. Dasar-Dasar Evaluasi Pendidikan Edisi 2. Jakarta: Bumi Aksara

Suwardi, dkk. 2014. Pengaruh Penggunaan Alat Peraga Terhadap Hasil Pembelajar Matematika Pada Anak Usia Dini. Jurnal Al-Azhar Indonesia Seri Humaniora, 2(4):297-305

Widiatmoko dan S. D. Pamelasari. 2012. Pembelajaran Berbasis Proyek UntukMengembangkan Alat Peraga IPA dengan Memanfaatkan Bahan Bekas Pakai. JPII.1(1): 51-56. 